\title{
An Insightful Assessment on Impact of Local Economic Development Programmes in South Africa and Nigeria: Linking Socio-Cooperative Connections and Youths' Participation
}

\author{
Nwachukwu, Precious Tobechukwu T. \\ University of Zululand \\ Email: precioustoby@yahoo.com \\ Prof Simon M Kang'ethe \\ University of Fort Hare, P/B X1314 Alice, 5700 \\ Email: skangethe@ufh.ac.za
}

Doi:10.5901/mjss.2014.v5n23p1621

\begin{abstract}
The study assembled insights comparison between two different Local municipalities in South Africa and Nigeria pertaining to youths' participation linked to some socio-economic status within the context of the Local Economic Development Programmes. The study made use of (n-160) youthful participants who participated in various LED programs out of a total number of (n-205) youths whom were multi-staged sampled. Data were analysed using multivariate inferential statistics and Pearson chi-square Test for independence correlations between variables (Lowry, 2002) and employed descriptive procedures recommended by Creswell (2007). This study revealed acute institutional challenges, indifference and supportive legal framework system and a significant effect with maturity level due to pedagogic attainment viable among certain age group range. It recommends the need for cooperative linkages of youths to substantive opportunities and increased informational knowledge of programmes using career survey assessment to ascertain matching skills capabilities within the youth's interest and their self-regulatory and self-efficacy.
\end{abstract}

Keywords: Youths, Participation, Programmes, Local Economic Development (LED), Unemployment, Umhlathuze, Calabar, Informational dissemination, Impact

\section{Introduction}

The rising level of poverty, unemployment, economic and social challenges confronting the youth in our communities has made the African Youth Charter (2005) to "supports the view that every youth has the right to participate in all scopes of the society." Studies have argued that career guidance services ought to be the requisite and conveyed to all stages of education to assist "students create genuine career selections effectively carried out in initial phases of life and as a rational approach aimed at decreasing the level of youth unemployment" (Ajufo 2013:316; Amadi, 2012:109). Studies have extensively discussed the phenomenon of youths' participation through early intervention schemes and career choices (Bender and Lombard, 2004; Sheppard and Cloete, 2009; Bayhan and Sipal, 2011; Strydom, 2012); and youths' attitudes towards programmes (Chikadzi and Pretorius, 2011; Olaniyan and Lawanson, 2010).

Examining the linkages between programmes designed for youths and relating youth's support to significant others or role models to enhance participation have been studied (Lerner, 2004; Brennan, Barnett and Baugh, 2007). Studies have equally deliberated on challenges pertaining to complexity of youth's education, training and labour market within the economy (Odada, 2004; Iwayemi, 2013; and Breuer, 2002). Some studies explored challenges of information dissemination issues to galvanised youths' involvement (Molly, White and Hosfield, 2002; Ashford, 2007).

This article revolves around the ideas that 'social workers, psychologists, community development workers and other social service practitioners have a duty to develop their own amassed knowledge and delineate practice skills through local inputs' (Osie-Hwedie, 2002:321), and also the contention espoused by Gray, Crofts and Healy (2001) that community based support services for social entrepreneurship as an accompaniment and service recipients' choices for progression, reflecting on what contributions they make to eliminate poverty through the assessment of Local Economic Development (LED) programmes geared to ensure involvement of youths in them (Chikadzi \& Pretorius, 2011: 266).

This would require engaging them at the tender level to occupational survey assessment with collaboration of the 
community schools to clarify their aspiration and the establishment of entrepreneurship education with business philosophy framework (Fatoki and Chindoga, 2011: 169) of "school-based community partnership grounded on commercial orientation" as practical training (Bender and Lombard, 2004). Looking at policies and approaches for youth's participation in local economic development for empowerment of young people, there has been little significant impact geared towards professional survey assessments to ascertain youths' interests on matched abilities and skills.

\section{Problem Statement}

Apparently, although the two countries of South Africa and Nigeria are in different part of Africa and of course constitute different and divergent geographical locale, literature and situations on the ground seems to suggest similarity in the state of youth unemployment. In South Africa, the situation is presented by Statistic South Africa that recorded an unemployment rate of $25.5 \%$ in the third quarter of 2012 which is an increase on the previous quarters of 24.9\%" (Statistics SA, 2012) while the National Youth Policy (2009-2014) citing the Labour Force Survey (Statistics SA, 2007) reported that "7,800,000 unemployed persons in South Africa young people accounted for 73 per cent of the unemployed i.e. about 5,600,000 million." Nigeria has also presented more or less same state of affairs with Emunemu (2008:28) observing that "over $70 \%$ of the unemployed in Nigeria were youths within $15-25$ years of age."

Apparently, a deeper reflection on the various policies of South African and Nigerian governments to empower the youths have not really impacted drastic changes even with Local Economic Development (LED) programmes channelled to the communities which have apparently revealed the character on the nature of the strategies employed to make them practicable. This presents a fertile ground to these researchers and other contenders to want to know the possible underpinning factors leading to this quagmire.

\section{Materials and Methodology}

The study embraced the multidimensional convenient sampling techniques used in sampling between eight to twelve communities each from Umhlathuze and Calabar in 2012. Non-experimental, quantitative survey approaches to qualitative interview of in-depth focus group discussions were employed within a triangulation pattern to glean data. The main instrument for the research is the Local Economic Development Programmes Sub-scale (LEDPSS) questionnaire that explored for general information about participants' socio-economic characteristics and other questions on participation, local government and community etc.

A total of $(n-245)$ questionnaires were distributed by trained enumerators familiar to the local dialect, but only ( $n$ 160) questionnaires were retrieved and deemed suitable for data analysis. The focus group interview discussions were conducted among the two aged ranges of youths i.e. 16-25year olds and 26-35 year olds comprising of three to five members in each age group in four different stages in both municipalities. The focus groups interviews lasted between 60 minutes and 90 minutes. Requisite ethical considerations were applied to protect the rights of participants and interview narratives were copied for analysis (Creswell, 2007; Newman, 2006). Also, employed statisticians were used to derive the coding and emerging themes.

The LED programmes in Umhlathuze Municipality that this study investigated included those of skills acquisition within CSI Partnership on training youths in building, agriculture, tourism ambassadors, internship and learnership within (SETAs) programmes. The trainees were graduates/students from the nearby University of Zululand, Tourism sector. Ngwelezane, Mandlazini Agricultural village, Phathane reserve, Ndondwane, Ndlangubo, Empangeni, eNseleni, Mevamhlope, Brackeham, Madlebe, Esakwa Mthethwa and Kwa Mkwanazi, were the communities involved under Umhlathuze Municipality of KwaZulu-Natal in South Africa.

In Calabar Municipality of Cross-River State in Nigeria, the communities that were part of the study included, Ikot Omin, Ediba Qua, Big Qua, Esuk Utan, Nasarawa Bacoco, Ikpai Omin, Ikot Effanga Mkpa, Ikot Eneobong, and Kasuk. The LED Programmes investigated agricultural and rural programmes which include Integrated Farmers Scheme; pineapple production, fish farming etc. Poverty alleviation programmes by the State and local governments administration in conjunction with the European Union Programmes on health, educational and skills acquisition, building of solar powered computer centers where equally included as part of LED/CSI initiatives in Calabar Municipality.

\section{Range and Delimitation of the Study}

The extent of the research study includes Calabar Municipality of Cross River State (Nigeria) and Umhlathuze municipality in KwaZulu-Natal Province (South Africa) as both have great capacities as one of the notably tourist 
destinations in their respective countries.

i. The focal objective of the study stood to evaluate the effect of youths' participation in Local Economic Development (LED) programmes in the selected study areas.

ii. The study selected interrelated Local Economic Development (LED) programmes and compares some socioeconomic status of the youths that avail themselves to participate in both research areas.

iii. To explore distinctive variables that could assist to improve Youths' participation in Local Economic Development programmes in both research areas.

\section{Data Analysis}

Data were analysed by employing both descriptive and inferential statistics to compare participation between the two countries. This entailed the use of tabulation with SPSS Version 19.0 to examine the Level of Participation, Gender, LED programmes distribution and Income of participants between UMhlathuze Municipality and Calabar Municipality from Nigeria. The Objectives i and ii stipulated in the objective section above were achieved using Pearson chi-square Test for independence correlations between variables for the participation level to achieve relationship between the dependent and independent variables. Objective iii was achieved using descriptive statistics were interview narratives were transcribed and copied (Creswell, 2007; Newman, 2006).

\section{Model Requirement}

Three levels of statistical analysis were conducted on the data. The Pearson 'Chi-square analysis Test for Independence was employed to achieve the relationship between the dependent variable and independent variables with the model' (Lowry, 2002) was tacitly stated as follows:

$\mathrm{Ho}_{0}$ : There is independence between variable $\mathrm{X}$ and $\mathrm{Y} ; \mathrm{H}_{1}$ : There is dependence between variable $\mathrm{X}$ and $\mathrm{Y}$; On the Chi-square test table reject the $\mathrm{H}_{0}$ if assumption significance 0.05 at $95 \%$ confidence, since the level of significance is less than 0.05 and reject the Null hypothesis and conclude that there is dependency between $\mathrm{X}$ and $\mathrm{Y}$.

Table i: Age Range and Gender of Participants

\begin{tabular}{|c|c|c|c|c|}
\hline Country & Gender & 16-25years & 26-35years & Total \\
\hline \multirow{2}{*}{ Calabar } & Male & $36(55.4 \%)$ & $18(62.1 \%)$ & $57(57.4 \%)$ \\
\cline { 2 - 5 } & Female & $29(44.6 \%)$ & $11(37.9)$ & $40(42.6 \%)$ \\
\hline \multirow{2}{*}{ Umhlathuze } & Male & $19(43.2 \%)$ & $8(36.4 \%)$ & $27(41.0 \%)$ \\
\cline { 2 - 5 } & Female & $25(56.8 \%)$ & $14(63.6 \%)$ & $39(59.0 \%)$ \\
\hline & Total & $109(68.1 \%)$ & $51(31.9 \%)$ & $100.0 \%$ \\
\hline
\end{tabular}

Source: Field Survey Data 2012.

\section{Findings and Discussions}

\subsection{Participation level on local economic development Programme.}

Questions pertaining to participation level were derived from subscale 7 of the Local Economic Development Programmes Sub-scale (LEDPSS) to evaluate how many days/times the participants spent weekly at the various development centers or being involved in the programmes? Participants indicated the amount of period spent in a week and month in their various LED programmes. Those who spent from 1-2 times/days per week regularly were graded as low level participants, while those who participated from 3-5 times/ days per week regularly were graded as high level participants. 
Table ii: Respondents' Participation Level Index across Municipalities

\begin{tabular}{|c|c|c|c|c|c|c|c|c|c|c|}
\hline Municipality & \multicolumn{3}{|c|}{ Participation Level Index } & \multicolumn{7}{|c|}{ Across Municipalities } \\
\hline CALABAR & LOW & $\mathrm{HIGH}$ & TOTAL & chi-square & Value & $d f$ & Asymp. & $\operatorname{sig}(2$ sided) & $\begin{array}{l}\text { Exact.sig } \\
\text { (2-sided) }\end{array}$ & $\begin{array}{l}\text { Exact.sig } \\
\text { (1-sided) }\end{array}$ \\
\hline 16-25years & $38(58.5 \%)$ & $27(41.5 \%)$ & $65(100 \%)$ & Pearson & $1.502^{a}$ & 1 & & 220 & & \\
\hline 26-35years & $13(44.8 \%)$ & $16(55.2 \%)$ & $29(100 \%)$ & Correlation & $1.500^{b}$ & 1 & & 317 & & \\
\hline Total & $51(54.3 \%)$ & $43(45.7 \%)$ & $94(100 \%)$ & Fisher's Exact Test & 1.500 & 1 & & 221 & .265 & .158 \\
\hline UMHLATHUZE & & & & & & & & & & \\
\hline 16-25years & $20(45.5 \%)$ & $24(54.5 \%)$ & $44(100 \%)$ & Pearson & $.496^{c}$ & 1 & & .481 & & \\
\hline 26-35years & $08(36.4 \%)$ & $14(63.6 \%)$ & $22(100 \%)$ & Correlation & .194 & 1 & & .660 & & \\
\hline Total & $28(42.4 \%)$ & $38(57.6 \%)$ & $66(100 \%)$ & Fisher's Exact Test & .500 & 1 & & .470 & .600 & .332 \\
\hline 16-25years & $58(53.2 \%)$ & $51(46.8 \%)$ & $109(100 \%)$ & Pearson & $2.013^{\mathrm{d}}$ & 1 & & & & \\
\hline 26-35years & $21(41.2 \%)$ & $30(58.8 \%)$ & $51(100 \%)$ & Correlation & 1.560 & 1 & & & & \\
\hline Total & $79(49.4 \%)$ & $81(50.6 \%)$ & $160(100 \%)$ & Fisher's Exact Test & 2.021 & 1 & & & .177 & .106 \\
\hline
\end{tabular}

Source: Field Survey data 2012, significant level at 0.05 and at 95\% confidence interval of the difference

Table 2 results overall shows that participation level has no significant effect in both areas, although Calabar and Umhlathuze recorded higher participation level among respondents between the ages of 26-35years with (63.6\%) for Umhlathuze and (55.2\%) for Calabar. Umhlathuze had higher level of participation within both age range of 16-25years (54.5\%) and 26-35 years (63.6\%) and a total ratio of (57.6\%), while Calabar had only (55.2\%) for the age range of 26-35 years. Majority of the respondents mostly the youths between the ages of 26-35year olds (58.8\%) have higher participation level than the youths between the ages of 16-25year olds, although youths 16-25year olds ( $n$-109) where more in number of participants than the 26-35 year olds youths (n-51).

\subsection{Local Economic Development (LED) Programmes Range}

On LED programmes, respondents were asked to indicate the type of LED programmes they are currently involved with or have previously participated in. This was derived from subscale 4 of the Local Economic Development Programmes Sub-scale (LEDPSS). Questions concerning respondents' views on LED programmes, the scope and spread of the programmes, their perceptions' and ways to improve on LED programmes and their economical viabilities to the communities were sought.

Table iii: Analysis on LED programmes dispersal involvement of respondents across countries

\begin{tabular}{|c|c|c|c|c|c|}
\hline Municipality & Age variable & Chi-square Test & Value & Df & Asymp \\
\hline \multirow{3}{*}{ Calabar } & $16-35$ years $(65 ; 100 \%)$ & \multirow{2}{*}{$\begin{array}{c}\text { Pearson } \\
\text { Like. Ratio } \\
\end{array}$} & $1.098^{a}$ & 4 & .895 \\
\hline & $26-25$ years $(29 ; 100 \%)$ & & 1.097 & 4 & .895 \\
\hline & Total & No of cases & 94 & & \\
\hline \multirow{3}{*}{ UMhlathuze } & $16-25$ years $(44 ; 100 \%)$ & \multirow{2}{*}{$\begin{array}{c}\text { Pearson } \\
\text { Like. Ratio }\end{array}$} & $10.674^{b}$ & 3 & .014 \\
\hline & $26-35$ years $(22 ; 100 \%)$ & & 10.747 & 3 & .013 \\
\hline & Total & No of cases & 66 & & \\
\hline \multirow{3}{*}{ Total } & 16-25years (109; 100\%) & \multirow{3}{*}{$\begin{array}{c}\text { Pearson } \\
\text { Like. Ratio } \\
\end{array}$} & $3.941^{\mathrm{c}}$ & 4 & .414 \\
\hline & $26-35 y e a r s(51 ; 100 \%)$ & & 3.954 & 4 & .412 \\
\hline & Total & & 160 & & \\
\hline
\end{tabular}

Source: Field Survey data 2012, significant level at 0.05 and at 95\% confidence interval of the difference

In Table 3, there is a significant impact on youths' participation in LED programmes at Umhlathuze having (0.14) which is less than expected impact of (0.05) for youths of 16-25 year olds and (.013) for youths of 26-35 year olds which is also less than expected impact of (0.05). Whereas in Calabar there were no significant impact on youths' participation as (.895) were accounted for both age ranges of 16-25 year olds and 26-35 year olds which are higher than expected impact of (0.05). The outcome of this finding could be as a result of consistent Corporate Social Investment (CSI) initiatives with intense information channels to communities at Umhlathuze Municipality coupled with the development of Sectoral 
Educational Training Authority (SETA) striving in Umhlathuze than in Calabar. The finding of this study correlates with the empirical findings of Taylor and Derek (2009:8) and Schaefer (2004) that revealed that well informed persons on programmes initiated in their localities avail themselves to participate.

\subsection{Income level Benefits from Participating in LED}

Income level and participation of the respondents was derived from self-reported responses from questionnaires where participants were asked to fill in in questions from the subscale 5 of Local Economic Development Programs Sub-scale (LEDPSS). The questionnaire has an in-depth interview questions that sought to rationalize the income generated from participation, alternative income, occupational type etc.

Table iv: Chi-square Test analysis on participants' self-reported Income across countries

\begin{tabular}{|c|c|c|c|c|c|c|}
\hline Municipality & Age ranges & Total & Chi-square test & Value & Df & Asymp sig (2-tailed) sided \\
\hline \multirow{3}{*}{ UMhlathuze } & $16-25$ years & 44 & Pearson Like.Ratio & $11.769^{b}$ & 3 & .008 \\
\hline & $26-35$ years & 22 & Pearson Like.Ratio & 12.391 & 3 & .006 \\
\hline & Total & 66 & No of cases & 66 & & \\
\hline \multirow{3}{*}{ Calabar } & $16-25$ years & 65 & Pearson Like.Ratio & $2.445^{a}$ & 3 & .485 \\
\hline & $26-35$ years & 29 & Pearson Like.Ratio & 2.561 & 3 & .464 \\
\hline & Total & 94 & No of cases & 94 & & \\
\hline \multirow{3}{*}{ Total } & $16-25$ years & 109 & Pearson Like.Ratio & $7.927^{c}$ & 3 & .048 \\
\hline & $26-35$ years & 51 & Pearson Like.Ratio & 7.523 & 3 & .057 \\
\hline & Total & 160 & No of cases & 160 & & \\
\hline
\end{tabular}

Source: Field Survey data 2012, significant level 0.05 and at 95\% confidence interval of the difference

Table 4 shows that the correlation between income levels generated from participation in LED programmes were highly significant in Umhlathuze (.008) for young people between the ages of 16-25 year olds and (.006) for 26-35 year olds which is less than (0.05). There are no significant income levels impact on LED Programmes in Calabar as she has (.485) for 16-25 year olds and (.464) for 26-35 year olds which is higher than expected (0.05). Inclusively, income level assessments generated from participation overall have significantly impacted on participants with (0.48) for 16-25 year olds for both Umhlathuze and Calabar Municipalities respectively than (.057) for 26-35 year olds for Umhlathuze and Calabar correspondingly. This study finding on income level generation from LED programmes has impacted on youths at Umhlathuze than youths in Calabar. This finding of the study correlates with the observation by Baker (2000:98) which asserted that during the 'TRABAJAR programme in Argentina, assessment of income enhancements by participants showed that additional incomes were profited from involvement to the programme'.

\subsection{Excerpts from the focus group interview discussions with youths that participated in LED in the study area (Source: field survey data 2012)}

Focus-item1: Choices of LED Programmes- Participants discussed the motivation behind their choice on the type of LED programmes they participated such as building, agriculture, tourism, internship and learnership within (SETAs) and European Union programmes.

Sub-item: Where did you get the information about the LED programmes in your locality? The intriguing replies as to how they gathered information on programmes, whether from their peers, family or significant persons that led to shaping their choices of the LEDs programmes they will participate in or if they assessed their personality traits that would enhance their ability to be in the specific programmes that would actuate their disposition.

- "We learned about the LED programmes when our youth leader in our ward informed us about it during the meeting of the youths' forum meetings" (Youths from IkpaOmin, 26-35years).

- "Personally, my parents informed me about it during the holidays and I informed my friends before we agreed to join the pineapple farming scheme"... "The scheme according to our parents has helped some young ones in our neighboring local government area to be productive.....as they make additional income" (Youths from Nasarawa Bacoco, 16-25years). 
- "We got the information from the daily Newspapers on advertisement on the SETAs...after my matric, my uncle suggested that I should learn electrical engineering, yet no available resources......my friend here informed me on the block making programme at Mandlazini supported by RBM"... (Youths 16-25years at UMhlathuze).

- "The Municipality was offering scholarship for community members in my area.., My friends informed me about it...that's how we ended up in this programme" (Youths 26-25 years at Brackeham).

The participants showed the "demand side preparations" for information disseminations on which LED programmes that are available to them within their localities correspond with the theory of Social Cognitive theory (Bandura, 2005). This informational dissemination tend to channel youths behaviour towards participating in LED programmes through "an exact central set of determinants and mechanisms" over their efforts and the best conducts in interpreting this knowledge (Bandura, 2005) of various LEDs around them.

The information the youths have about the LED programmes influences their attitudes toward the programme participation as they decipher they are viable and worthy involving or not (Olaniyan \& Lawanson, 2010). Fletcher \& Van Horn (2000) cited in Brennan, Barnett \& Baugh (2007) stated that active supportive and strengthening of parents with a good rapport to the youth, would encourage better impact to youth's involvement in the community than "parental modelling", but rather parents should connect their progenies to the real world of opportunities. The attitudes of youths towards participating in LED programmes could be observed through expected outcomes and the values that those outcomes are located there in.

Sub-item: Why did you choose the type of LED programme you are involved with? Participants acknowledged the social environmental factors that enabled them to choose the LEDs. Some of them were linked to their choices of past experiences derived from significant important persons in their lives.

- "We decided to enroll with the SETAs on health and welfare education"..."we enrolled as community health care givers...but I have always wanted to work in palliative care not only on community-based care"..."We have five days per week to attend courses and our mentorship lasts for six (6) months duration"..."Some of us enrolled in the management development programme to equip us with leadership skills especially for voluntary/non-profit organization section...the incentives offered by facilitators of these programmes have really assisted us" (Youths 26-35 years at Esakwa Mthethwa).

- "Past experiences from by my parents really motivated my choice of programmes to be involved in learning a skill than trading" (a youth participant 16-25 years at Ikot Eneobong)..."when the Cross River State government started the programme to eradicate motor-cyclists in Calabar metropolis....some of us saw our chance to own a taxi than to continue the okada (motor-cycle driving) business..." (Youths 26-35years at Big Qua).

- "We choose the Bank-SETA to further develop our skills and overall marketability in the future not only for the stipends being provided for the participants"....."I decided to choose the environmental conservation study since I graduated and this programme has enabled me to go further for my postgraduate study..." (Youth 2635years Empangeni)....." The tourism programme training of the municipality would help us to get a job from the tourism sector including the incentives....it would improve our Curriculum Vitae....we have to participate" (Youths 16-25years at Phathane Reserve).

This study findings support the argument that the self-efficacy of Social Cognitive of Bandura shows qualities inherent in the ability of the young persons to organize "control over expected costs and benefits outcomes" for participating in LED programmes within the goals that the youths set for themselves and their strategies and plans to realise them (Bandura, 2005); and also for youths' decision to the choice of LEDs to participate. Lerner (2004) agreed that in developing the youths to have active commitment in the community and involvement, youth development programmes should be designed to afford the provision of a role model i.e. an adult the youth can build for a 'sustainable association amid skill-enhancing prospects.'

Focus-item 2: Participation Level Index- Participants discussed issues related to the days they were involved in the LED programmes;

Sub-item: How many times do you avail yourself to be at the establishments? The participants were not happy on how the programmes were being administered and thus it affected their participation.

- "Most times we try to come thrice a week.... it depends on the availability of programmes directors...but the programmes schedule could specify four to five times a week...our greatest problem is lack of reliable 
electricity" (some youth participants 16-25years at Ikot Effanga Mkpa).

- "The literacy programmes schedule in our community were supposed to be held during the evening sessions but some of us are deeply occupied during the day...so we resort to coming during weekends which the programme directors had to restructure"(Youth participants 26-35years at Kwa Mkwanazi)

- "It is a waste of time if programme supervisors are not available.....most times there are postponement on schedule programmes....we end up coming may be once or twice a week...it's very frustrating" (Youth participants' 16-25years at Kasuk).

- "For us, we see the enrollment on the available SETAs as a means to fully get a stable employment....we avail ourselves to be punctual as we are seconded to the banking SETA...So we have to be at Empangeni every morning before $8 \mathrm{am} . . .$. you are an employee from 8am-4pm including weekends"... (Youth participants 26-35 years from Ngwelezane).

Iwayemi (2013:11), in addressing the problems of youth unemployment in Nigeria attributes it to lack of adequate "supply of energy or improvement of electricity and other infrastructural services". In the same vein, Galston (2001) found out that the more knowledge citizens get to know about things happening around them, the more is the possibility they would participate in public matters. Further to this is fact that students' participation in community-based activities or those "constant patterns of service activities during college" has a greater effect in participating in later community events (Galston, 2001: 232). The cooperative linkages of youths (Lerner, 2004) to substantive opportunities from stakeholders within the framework of youth's facilitators and important people that youths have good rapport with in their social environment i.e. families, friends could aid in defining the attitudes of their choice of LED programmes in the study areas. This encourages better involvement of youths in LEDs programmes.

Sub-item: Does your income levels affects your enrolment to the LED programmes in your locality? The discussions with participants sought to rationalize if income derived from participation in LEDs improved their participation and their well-being.

- "We believe that the local municipalities should increase the stipends for us working at the community centers......most of the children here in the crèche are mostly orphans and need proper care and some are from child headed households because of the devastating HIVIAIDS problem in the rural communities"(Youths participants 26-35 years at Mandlazini).

- "My participating in the "taxi scheme" have really enabled me to provide for my family as the way we remit payment for the higher purchase model gives me more additional income....before 12pm in the afternoon I would have completed the payment for the day, then from $1 \mathrm{pm}$ to $8 \mathrm{pm}$, all the money I get goes to my own savings" (Youth participant 26-35 years at lkot Eneobong).

- "The stipends offered by the SETAs, both for internship and learnership cannot equate the daunting tasks. We have to finish our assignments every day in the workplace. It is enormous.....we have to work on weekends.... we are not supposed to be available and we are not paid for overtime" (Youths participants16-25years at Ndlangubo).

The findings from the study correlates with what Chesoh (2010) and Baker (2000:9) contend that income was a key factor affecting participation and that stipend would improve participation in LEDs as participants would view such as stimulating alternative income. This study finding also depicts what Iwayemi (2013:5) in assessing barriers that hinders government policies to improve youths' participation programmes in Nigeria refers to as "large scale and medium term interventions which includes grants and financial support but lacks adequate stable macro-economic environmental plan to sustain job-creation."

\section{Focus-item 3: Difficulties to Sustainable Youth Participation in LED Programmes}

\section{Sub-item: What are the influences that impede participation by youths within LED programmes in your communities?}

- "There are a lot of indifferences towards participating because of lack of information dissemination on the part of facilitators. So, most of the times we are not aware of these LED programmes.... in Ediba Qua, here it is mostly the councillors, youth leaders and their relatives/friends and politicians who get the information first and use it to their advantages before they can inform us in the meetings" (Youths participants 16-25 years at Calabar).

- "At times, politicians hijack the processes and most of the times give it to their own communities rather than the needed community"...for example, the Esut Utan European Union funded Women and Youth's community 
center, built to promote entrepreneurship for local women and the youths here, has been given to businessmen who comes from other states and communities. The center is now used for different activities" (Youth participants 26-35 years at Calabar).

- "The European Union Computer programme skills acquisition learning here at Ikpai Omin has been hijacked by politicians and given to their relatives and political friends at the detriment of the community members that should have accessibility to the learner ship programme and usage".. (Youth participants' 16-25years at Calabar).

- "LED programmes are misprioritised by the municipal officials to the detriment of the community who exhibits the potential".... "In this Mandlazini Agricultural village, we should have more entrepreneurship programmes funded by the RBM.....serious commitment to assist our agricultural outputs by training our youths more in agricultural related schemes instead of the skills in making of building blocks and women working on crafts in the community center"(Youth participant 26-35years at Umhlathuze).

- $\quad$ "Placement on internship or learner-ship must be geared towards relevant workplace experiences that would make a difference to the youths' career"...."Most basic rights of youth's participants have been abused since there were no structures to address these imbalances....we are not given any incentives for overtime etc... nobody to complain to "as termination from the firm...is termination from the programme" (Youth participants 26-35years at Empangeni).

- "When we volunteered for the community health care programme the situation was very critical as the facilitators were biasedly focused on curative measured services than preventive and prevalence rates soar high due to dearth of orientation training, low awareness amid staff .... At times essential drugs for peculiar diseases commonly found in the locality are not readily available" (Youths participants 26-35 years at Ikot Eneobong).

This study finding shows acute institutional challenges that can be attributed to the dearth of training for health care youth volunteers in Calabar and also on placement on relevant work settings for participating youths in SETAs at Umhlathuze. This mirrors what Labaran (2009) and Salako (2009) contend that infrastructures should be upgraded to enable participants gather requisite skills enhancement and that participation by community members is marginal at serious opinions of decision-making level. Olaniyan \& Lawanson (2010) observed that "austere budgetary constraints and uneven distribution of resources among the urban and rural areas" with the rural areas mostly affected by inequitable budgetary health expenditure allocation and programmes inept progress even with huge budget. Odada (2004) in assessing instructional challenges impeding effective participation asserts that deficiency of institutions as a result of political issues, technical issues or economic issues associated with development programmes could be curbed for effective use of shared resources.

Iwayemi (2013:3-8) in listing the various challenges facing youth unemployment includes "lack of demographic transition, high cost of governance which reduction can stimulate funds for youth employment, weak integration of Small, Medium and Micro Enterprises (SMEs) to the national industrial sectors of the economy thereby minimising the entrance of youths as entrepreneurs and job creators." Breuer (2002:18) stresses the importance of personal commitment on the part of senior managers and politicians to avoid "tokenism and alienation of community in order to unlock community capacity, creativity and energy" in highlighting hindrances to participation due to politicization and uneven distribution of LEDs.

This study discloses indifference through deficiency on institutions challenges with miss-match priority for learners, deficient realities of the areas by facilitators and political corruption that have resulted to uneven distribution of LED programmes have been the crux of problem plaguing youth's participation.

\section{Discussions on the Findings}

In examining the LEDs programmes, information dissemination in both study areas showed negative impact by youths participating in them even though there were glimpses of corporate social investment in UMhlathuze and the government efforts in training and educating youths abroad in Nigeria. However, the reality is that both countries are witnessing high rate of youth's unemployment. The overall income derivational impact did not fare better in both study areas although 1625 year olds at UMhlathuze has a significant difference. There are many strenuous variables that have attributed to these findings such as lack of macro-economic environmental plan to sustain job-creation, high cost of governance (Iwayemi, 2013). Other factors such as political corruption impede funds to promote youth's programmes (Odada, 2004). Also lack of personal commitment by facilitating officials also poses a serious deterrent (Breuer, 2002).

Concerning information dissemination pertaining to the Local Economic Development Programmes, Ashford, 
(2007: 25) and Molly, White \& Hosfield (2002: 29) have established that young people lack of access to infrastructure, internet and social media as per information and communication technology (ICT). They also face "a lack of awareness and understanding about the role and duties of local government, misunderstanding pertaining to the difference concerning national and local government." They are affected by negative perceptions of national politics. The difficulties pertaining to comprehend the complexity in the relationship between training, education and labour market and trepidations about lack of arrangement between the sustainable needs of the economy and the education system are worrisome scenarios for most youths (Ashford, 2007; Sheppard \& Cloete, 2009; Emunemu, 2008). The level of education and information dissemination can effect inclination and choice of job as indicated by Taylor \& Derek (2009) that higher education assists to stimulate participation in developmental programmes depicting the vital role of career surveys assessment to link LED programmes.

On the overall, youths participation in LED programmes have been more acceptable by youths within the age range of 26-35 years even though they have lower numbers of participants in the programmes. This finding by the study could be as a result of maturity or level of educational attainment which enables members of the community to identify themselves with any programmes that are economically viable within this age group range the researcher argues.

\section{Conclusion and Recommendations}

The researchers argue that there is need to tackle poverty, inequality and unemployment which are the triple prevalent problems in the societies of both South Africa and Nigeria, and many African countries at large. There is a need to challenge the unworkable policies to indigenize feasible ones (Osie-Hwedie, 2002a; Gray et al, 2001). This study envisaging from the perspectives of Social Development Model and also within the context of Community Development Strategies for sustainable livelihood and in designing new apparatus for engaging youths as part of economic development recommend the followings:

- That socio-cooperative linkage encompasses the cultural perspectives geared towards youths' participation, creation of assessment, and increased informational knowledge on career paths for young people.

- That the socio-cooperative linkages would assist to derive from the youths' perceptive and self-competences surrounded by the important role models the youths looked up to in the communities at participation location.

- Assessment within socio-cooperative linkages should link to substantive opportunities to ascertain matching skills capabilities within the youth's interest, their self-regulatory and self-efficacy.

- This should involve the engagement of youths at the tender level within the student/ graduate internship/ learnership scheme toward career survey assessment through collaboration with the community schools, leaders of thought/significant role models and families' networking.

- Cultural views should be communal orientations and spirituality concepts that incite values to participation and help to address the types of LEDs the youths would be linked to through intellectual/skills capacity building with human and social services practitioners engaged to the communities and for actualising LEDs suitability for youths' own capabilities.

- The Socio-cooperative linkages would also involve the employing of comparative approach for various governmental departments and agencies in accessing workable policy through cooperation of municipalities etc. Social service practitioners are required to present extensive range of legal framework in fashioning for young people who are involved in LED programmes to have support system where monitoring their progress as well as strict adherence to packages enshrined in the programmes by firms /facilitators.

- Further studies should be channelled in investigating the orientation mechanisms of LED programmes towards incentive entrepreneurship placement of youths and the expansion of the concept socio-cooperative linkages as home-grown concept to social development.

- In summary, this study in validation to Galston (2001) and Lerner (2004) on community based activities and cooperative linkages for youths pertaining to LED programmes, has discussed the perceived attitudes that youths have that could have stagnated proper enrolment to LEDs.

Further studies should investigate the exploration of entrepreneurial career oriented with indigenous alternative approaches (socio-cooperative linkages) amid welfare schemes to propel and incite youths participation. The examining of youths' self-efficacy and matching interest derived from evaluating LEDs programmes attachment by youths' participants should be the focus realignment for human and social service professionals.

This focus will assist in optimizing young peoples' potentials and involvement in LED programmes to curb the findings derived from this study being misprioritised placing of LEDs, institutionalized challenges as well as empathic personal commitment on the part of facilitators in the study areas. 


\section{References}

African Union (2005). African Youth Charter. Addis Ababa: African Union. Available from: http://www.au.int/en/sites/default/files lafrican_youth_charter.pd [Accessed on 25 August 2011].

Ajufo, B. I. (2013). Challenges of Youth unemployment in Nigeria: Effective Career Guidance as a Panacea. African Research Review. An International Multidisciplinary, Ethiopia, 7(28), 307-321. Available from: http://dx.doi-org/10.4314/affrev.v.d/21 [Accessed on 8 June 2013].

Amadi, P. (2012). Agricultural entrepreneurship development for youth empowerment in Nigeria: Constraints and Initiatives for Improvement. Education and Social Research, 2(10), 107-114.

Ashford, L. (2007). Africa's youthful population: Risk or Opportunity? Washington, DC: Population Reference Bureau.

Baker, J. (2000). Evaluating the impact of development projects on poverty: A handbook for Practitioners. Washington DC: The International Bank for Reconstruction and Development/ World Bank.

Bandura, A. (2005). Evolution of social cognitive theory. In K.G. Smith \& M.A. Hitt (Eds.), Great minds in management, 9-35. Oxford: Oxford University Press.

Bender, G. \& Lombard, A. (2004). A Personal and interpersonal effects of a Life skills Programme on Grade 7-learners. Social Work. 40 (1), 87-106.

Brennan, M., Barnett, R., and Baugh, E. (2007). Youth Involvement in Community Development: Implications and Possibilities for Extensions. Journal of Extension. 45 (4). Available from: www.joe.org. [Accessed on 31 May 2013].

Breuer, D. (2002). Community participation in Local Health and Sustainable Development. Approaches and Techniques. European Sustainable Development and Health Series 4. EUR/ICP/POLC06035D (rev.1). ISBN92 89010843.

Chesoh, S. (2010). Community perception, satisfaction and participation toward power plant development in Southern most of Thailand. Journal of Sustainable Development, 3(2), 84-88.

Chikadzi, V. and Pretorius, E. (2011). Unhelpful Help: The Social Work Profession's Response to Mass Poverty in South Africa. Social Work/Maatskaplike Werk, 47(3), 255-269.

Creswell, J. (2007). Research Design: Quantitative, Qualitative and Mixed Methods Approaches. Thousand Oaks: Sage Publications.

Emunemu, B. (2008). Private Sector Participation in Education and Skills Development in Nigeria. European Journal of Social Science, 6(4), 166-170.

Fatoki, O. and Chindoga, L. (2011). An investigation into the obstacles to Youth Entrepreneurship in South Africa. Journal of International Business Research, 4(2), 161-170. Canadian Centre of Science and Education. Available from: www.ccsenet.org/ibr. [Accessed on 16 May 2013].

Galston, N. (2001). Political knowledge, political engagement and civic education. Annual Review: Political Science, 4, $217-234$.

Gray, M., Croft, P. and Healy, K. (2001). Social Entrepreneurship: Whose responsibility is it any way? Paper presented to the Social Entrepreneurship Workshop Centre for Full Employment and Equity and the Department of Social Work. The University of Newcastle. 21 November 2001

Iwayemi, A. (2013). Youth unemployment in Nigeria- Challenges and way forward. A Paper presented at the World Bank Regional Workshop on Youth Employment. Abuja. July 23-24, 2013. Available from: www.slideshare.net/iegfeedback/youthunemployment-in-nigeria-challenges-and-way-forward [Accessed on 02 October 2013].

Labaran, I. (2009). Building bridges between the levels of health services. In Effective Primary health care delivery in Nigeria. Workshop Summary. Forum on Evidence-based Health policy making. The Nigerian Academy of Science. West African Book Publishers. Available from: http://www.nas.org.ng/index.php?..effective...delivery-in-nigeria-workshop-shtm. [Accessed on 03 June 2012].

Lerner, R. (2004). Promoting positive youth development: Theoretical and Empirical bases 1. Institute for Applied Research in Youth Development, Tufts University. Available from: http://ase.tufts.edu/iaryd/documents/pubpromotingpositive.pf. [Accessed on 02 April 2013].

Lowry, R. (2002). Chi-square procedures for the analysis of categorical frequency data. Available from: http://www.Macintosh\%2OHD/webtest/\%A5-PS-Preview-htm. [Accessed 07 June 2012].

Molloy, D., White, C. and Hosfield, N. (2002). Understanding youth participation in Local Government: Prepared for DTLR. Available from: www.liv.ac.uk/politics/staffpage/YCC_Literature_Review.pdfn. [Accessed 25 June2012].

National Youth Policy of South Africa (2009-2014). Available from: http://www.thepresidency.gov.za/MediaLib/Downloads/pfd [Accessed on 30 April 2013].

Neuman, T. (2006). Basics of Social Research: Qualitative and Quantitative Approaches. Boston: Pearson//Allyn and Bacon.

Odada, O. (2002). Enabling environment for effective implementation of water management for Food and Ecosystems and for poverty alleviation and sustainable development. Report of the African pre-conference on water for food and ecosystems- Addis Abba, 46 November, 2004. Available from: http://www.fao.org/ag/wfe2005/doc/annex_c3.pdf [Accessed on 13 June 2012].

Oladipo, F. and Adekunle, O. (2010). Empirical Determination of Socio-economic Status and its relationship with selected characteristics of rural male farmers in Kwara State, Nigeria. Research Journal of Agriculture and Biological Sciences, 6 (1), 64-76. INSInet Publication.

Olaniyan, O. and Lawanson, A. (2010). Health Expenditure and Health Status in Northern and Southern Nigeria: A Comparative Analysis using NHA Framework. Paper presented at the 2010 CSAE Conference held at St Catherine College, University of Oxford, Oxford, UK. Available from: www.csae.ox.ac.uk/conferences/2010-EDiA/.../451-Lawanson [Accessed on 27 July 2012].

Osie-Hwedie, K. (2002a). Indigenous Practice-Some Informed Guesses: Self-evident and Possible. Social Work/Maatskaplike Werk, 
38(4), 311-29.

Salako, L. (2009). Essential drugs and Equipment in Primary Health Care. In Effective Primary Health Care delivery in Nigeria. Workshop Summary. Forum on Evidence-based Health Policy making. The Nigerian Academy of Science. West African Book Publishers. Available from: http://www.nas.org.ng/index.php?.effective..delivery-in-nigeria workshop-shtm. [Accessed on 03 September 2012].

Schaefer, R. (2004). Sociology: A brief introduction 5th Ed. New York: Palgrave Publishers.

Sheppard, C. and Cloete, N. (2009). Scoping the Need for Post-School Education'. In: N. Cloete, ed. Responding to the Educational Needs of Post-school Youth. Wynberg: Centre for Higher Education Transformation and the Further Education and Training Institute

Statistics in Brief (2012). Statistics South Africa. Pretoria: Government Press. Available from: www.statssa.gov.za/publications/StatsInBrief/StatsInBrief2010.

StasSA Statistics South Africa (2007). Labour Force Survey PO210. Pretoria: StasSA.

Taylor, S. and Derek, Y. (2009). Importance of Socio-economic status in determining Educational achievement in South Africa. Stellenbosch Economic Working Papers.

Matieland, University of Stellenbosch. Available from: http://ideas.repec.org/p/sza/wpaper/wpapers73.htm. [Accessed on 03 June 2012]. 